\title{
Electronic Human Resource Management (e-HRM) of Hotel Business in Phuket
}

\author{
Kitimaporn Choochote \\ Faculty of Technology and Environment \\ Prince of Songkla University, Phuket Campus \\ Phuket, Thailand
}

\author{
Kitsiri Chochiang \\ Faculty of Technology and Environment \\ Prince of Songkla University, Phuket Campus \\ Phuket, Thailand
}

\begin{abstract}
This research aims to study the pattern of the electronic human resources management (e-HRM) of the hotel business in Phuket. The study is conducted with the implementation of field data and in-depth interview of hotels' HR managers. In consequence, the study reveals that the hotel business has applied the use of the e-HRM varying in job recruitment (15 percent), employee engagement (55 percent), organizational file structure (10 percent), idea and creativity exchanges (38 percent) and assessment system (6 percent). However, considered as 100 percent, the hotel business has not prepared to apply the use of the e-HRM in salary system, learning and training program, welfare allocation and career development.
\end{abstract}

Keywords - electronic human resource management; e-HRM; hotel business; e-learning; Management

\section{INTRODUCTION}

The information technology has been developed and advanced drastically over time. Therefore, several organizations are attempting to highly develop themselves and demonstrate their leaderships and professional visions of the industry. Admittedly, the human resources department is considered as the most significant part in all business organizations as it concerns greatly with intellectual skills, required abilities and work-related experiences of employees in the organization. A large number of technologies have been applied to facilitate the management of human resources. The e-HRM plays a vital role in human resources management [1] where procedures and processes can be less complicated [2] while ensuring accuracy [3] and timeliness of communication between both organizations and employees with unlimited distance of message transmission. This helps reduce work complexities [4] and stimulate the employees to work effectively.

A massive number of investments have been generated in the alignment of the hotel business [5], thanks to a rapid expansion of transportation and tourism industries that help drive economic growth for the country. Consequently, it can be said that effective human resources management is compulsorily required for all business organizations. The implementation of the e-HRM in the hotel business is very important as it helps a certain organization to achieve its goal in a precise and speedy manner [6], [7], [8], [9].

Research Fund of Faculty of Technology and Environment, Prince of Songkla University (PSU), Phuket Campus

\section{ELECTRONIC HUMAN RESOURCES MANAGEMENT MODEL}

The e-HRM is considered as one of the key factors that every organization needs to focus. Everything will be performed via electronic solutions and, as a result, it can help an organization to move forward quickly. The innovative eHRM can ensure no redundant works or waste of time and human resources. The e-HRM consists of 9 important systems [10] described as follows.

\section{A. Recruitment System}

An online job application starts with downloading of an online application form with regard to the preferred position and qualifications required for the job. It is required to submit the online application form via the system, in which the system will begin to perform its preliminary screening process with, for instance, the use of keywords or special skills required by the applied position [11], [12]. After the preliminary screening process, an interview session will come into consideration. An applicant will be asked to describe personal information, required skills and work-related experiences or tested for the attitude [13], [14] and professionalism towards the position [15], [16]. The final step of the online recruitment system concerns greatly with schedules and appointments, which can quickly be confirmed via email, SMS or phone.

\section{B. Employee System}

The employee system can effectively manage the basic data of employees via networking system. An employee can feel free to add, delete and edit personal profile. The system is also connected to other data and information where an employee can manage them personally and completely such as making a leave request, in which an employee can see the exact number of leave days while being able to make a leave request directly via the computer. This can facilitate a manager to approve such leave request in an immediate manner as both the employee and the manager can view the details of leave request fully. [17] Meanwhile, another important point in the employee system is an employee can make a reservation for car, conference room and other facilities in the organization in advance to ensure promptness prior to the actual date of use [18], [19], [20].

\section{Basic Organizational Information Management System}

To create a good organizational structure, high-ranking executives are required to understand the nature of organization as well as work function and performance that keep changing 
constantly. A good organizational structure will also reflect in clear vision, mission and value in order to encourage all employees to achieve a mutual goal. In doing this, all employees must have a good cooperation and harmony to ensure that the organization can move forward rapidly and strongly. Determining the organizational structure is also important as each employee can clearly understand their roles and responsibilities [21]. Therefore, the reception of organizational information via the networking system, such as website or share drive, will generate quicker and clearer overview of such information [22].

\section{Salary Management System}

Obviously, this system will be accessed by an employee at least once a month. Salary management, of course, concerns mostly with salary, remuneration and overtime payment received from the organization. However, there will be some deduction amount, such social security, as found in the system. Also, the system will facilitate an employee with an automatic calculation of both income and deduction amount of each month. The net amount of salary will show to the calculation of tax to be paid to the government. An employee is allowed to access to the salary management system and print out a salary slip only when necessary [23].

\section{E. Learning and Training System}

The learning and training system will encourage all employees to maximize skills, increase knowledge and improve attitudes. Generally, the learning or training program will be promoted via an announcement. If an employee has an interest in a certain program, he or she can proceed with the application with specified date and time via email. The system will send an alert message to the employee to confirm the previous registration. As the learning or training program is completed, the employee is required to share knowledge gained from such learning or training program with others [24]. This system will enable the organization to visualize the enthusiasm and learning ambition of the employees, considered as a significant tool for the assessment of employee performance [25], [26].

\section{F. Idea and Creativity Exchange System}

The idea and creativity exchange system is developed to stimulate the management of self-responsibility for each employee, where different ideas and viewpoints received from meetings, daily conversations and social network can be shared [27]. Employees are allowed to present new ideas or creativities in Facebook or web board, as part of the intention to let them have a good cooperation in making all tasks achievable [28], [29].

\section{G. Assessment System}

For the assessment system, it is required to rely on the online or intranet program that can easily and quickly facilitate the calculation. Strategically, there are two types of assessment. Firstly, an employee is required to conduct a selfassessment. The employee will be motivated to work effectively towards the targeted goal. Secondly, an employee is required to have an assessment conducted by a respective manager. This type of assessment can determine the employee's career development and it has a direct effect in salary and welfare adjustment when the assessment result is officially revealed [30].

\section{H. Welfare System}

Employees can be motivated by the welfare system, which helps build the fairness in receiving necessary remunerations including allowance, travel expense, provident fund and bonus. Admittedly, the welfare was judged and assessed by the rate of sense and feeling in the old days and it consequently led to conflicts between both the employees and the organization. However, due to the prolonged economic slowdown, several organizations have decided to eliminate unnecessary expenses. The development of the welfare system will help reduce nonbeneficial costs as all employees will be offered appropriate welfares considered as limitation of individuals. The welfares offered to the employees are designed to suitably meet the targeted organizational goal in accordance with the limitation of individuals in the database [31], [32].

\section{Career Development System}

This is the final system developed to highly facilitate the eHRM, which aims at the achievement of the organization. However, the most significant factor in the organizational development is personnel or employee management. [33] As different employees have different skills and abilities, it is required to bring out their most excellent skills and abilities to ensure that each task can be accomplished thoroughly with regard to their educational backgrounds, work-related experiences and special qualifications to be evaluated by their respective managers, as part of the ambitious goal to pursue the 'Put the right man on the right job' concept [34].

\section{PURPOSE OF THE RESEARCH}

To study the pattern of the e-HRM of the hotel business in Phuket

\section{RESEARCH METHODOLOGY}

People involved in the research were human resources managers and other personnel involved in the human resources tasks belonged to hotels in Phuket with more than 200 guest rooms, totaling 57 hotels.

The instruments of this research focused on qualitative methods, with the collection of field data and the in-depth interviews with human resources managers and other personnel involved in the human resources tasks in the hotel business.

\section{FINDING}

The findings of the research on E-HRM of hotel business in Phuket were:

\section{A. Demographic data}

TABLE I. POSITION OF THE INTERVIEWEE

\begin{tabular}{|l|l|l|}
\hline Position & Number of hotels & Percentage \\
\hline HR Manager & 25 & 50.0 \\
\hline Assistant HR Manager & 10 & 20.0 \\
\hline Other & 15 & 30.0 \\
\hline Total & 50 & 100 \\
\hline
\end{tabular}


TABLE II. GENDER OF THE INTERVIEWEE

\begin{tabular}{|l|l|l|}
\hline Gender & Number of hotels & Percentage \\
\hline Male & 11 & 22 \\
\hline Female & 39 & 78 \\
\hline Total & 50 & 100 \\
\hline
\end{tabular}

B. Hotel Information

TABLE III. NUMBER OF ROOMS IN THE HOTEL

\begin{tabular}{|l|l|l|}
\hline Hotel rooms & Number of hotels & Percentage \\
\hline 200-250 rooms & 23 & 46 \\
\hline 251- 300 rooms & 8 & 16 \\
\hline 301-350 rooms & 5 & 10 \\
\hline more than 351 rooms & 13 & 26 \\
\hline Total & 50 & 100 \\
\hline
\end{tabular}

TABLE IV. NUMBER OF EMPLOYEES

\begin{tabular}{|l|l|l|}
\hline Number of employees & Number of hotels & Percentage \\
\hline $0-100$ & 2 & 4 \\
\hline $101-200$ & 19 & 38 \\
\hline $201-300$ & 10 & 20 \\
\hline $301-400$ & 9 & 18 \\
\hline $401-500$ & 2 & 4 \\
\hline more than 351 rooms & 8 & 16 \\
\hline Total & 50 & 100 \\
\hline
\end{tabular}

C. Information of electronic Human resource management

\section{1) Recruitment System}

TABLE V. JOB APPLICATION

\begin{tabular}{|l|l|l|}
\hline Job application & Number of hotels & Percentage \\
\hline wall in & 1 & 2 \\
\hline walk in and by emailing & 41 & 82 \\
\hline walk in and by mailing & 1 & 2 \\
\hline No additional staff & 1 & 2 \\
\hline by emailing and hotel website & 6 & 12 \\
\hline Total & 50 & 100 \\
\hline
\end{tabular}

TABLE VI. AN APPOINTMENT TO INTERVIEW FOR THE JOB

\begin{tabular}{|l|l|l|}
\hline An appointment & Number of hotels & Percentage \\
\hline Only informe by phone & 33 & 66 \\
\hline Informe by phone and emailing & 17 & 34 \\
\hline Total & 50 & 100 \\
\hline
\end{tabular}

TABLE VII. NOTIFICATION OF ACCEPTANCE

\begin{tabular}{|l|l|l|}
\hline Notification of acceptance & Number of hotels & Percentage \\
\hline Tell immediately or call & 34 & 68 \\
\hline $\begin{array}{l}\text { Tell immediately or call and send } \\
\text { email to confirm }\end{array}$ & 16 & 32 \\
\hline Total & 50 & 100 \\
\hline
\end{tabular}

2) Employee System

TABLE VIII. THE EMPLOYEE RECORDS

\begin{tabular}{|l|l|l|}
\hline Employee records & Number of hotels & Percentage \\
\hline Time recorder & 7 & 14 \\
\hline Finger scan & 43 & 86 \\
\hline Total & 50 & 100 \\
\hline
\end{tabular}

TABLE IX. EMPLOYEE'S LEAVE

\begin{tabular}{|l|l|l|}
\hline Employee's leave & Number of hotels & Percentage \\
\hline $\begin{array}{l}\text { Write a letter on paper, approved } \\
\text { by the department head and send } \\
\text { to HR department }\end{array}$ & 45 & 90 \\
\hline $\begin{array}{l}\text { Write a letter on paper, approved } \\
\text { by the department head, filling } \\
\text { system and send email to } \\
\text { HRdepartment }\end{array}$ & 3 & 6 \\
\hline $\begin{array}{l}\text { Leave online by entering their } \\
\text { username and passpord, the sytem } \\
\text { will send to department head and } \\
\text { forward to the HR department }\end{array}$ & 2 & 4 \\
\hline Total & 50 & 100 \\
\hline
\end{tabular}

TABLE X. RESERVATION ON A MEETING RoOM AND CAR OF EMPLOYEES

\begin{tabular}{|l|l|l|}
\hline $\begin{array}{l}\text { Reservation a meeting room and } \\
\text { car }\end{array}$ & Number of hotels & Percentage \\
\hline Phone only & 10 & 20 \\
\hline By email only & 22 & 44 \\
\hline Paper only & 4 & 8 \\
\hline By phone and email & 6 & 12 \\
\hline Paper and email & 2 & 4 \\
\hline $\begin{array}{l}\text { By email and inform to } \\
\text { department head }\end{array}$ & 1 & 2 \\
\hline unknow & 1 & 2 \\
\hline Total & 50 & 100 \\
\hline
\end{tabular}

\section{3) Enterprise System}

TABLE XI. ENTERPRISE INFORMATION MANAGEMENT

\begin{tabular}{|l|l|}
\hline Information management & $\begin{array}{l}\text { Number of } \\
\text { hotels }\end{array}$ \\
\hline Notice board & 22 \\
\hline Present on orientation & 20 \\
\hline Employee handbooks & 10 \\
\hline
\end{tabular}




\begin{tabular}{|l|l|}
\hline Inform the department head during the meeting & 6 \\
\hline Hotel website & 4 \\
\hline Department head tell subordinate & 1 \\
\hline Share drive & 1 \\
\hline unnecessary & 3 \\
\hline
\end{tabular}

4) Payroll Management System

TABLE XII. SALARY DOCUMENT

\begin{tabular}{|l|l|l|}
\hline Salary document & Number of hotels & Percentage \\
\hline Carbon slip & 26 & 52 \\
\hline Pay slip & 24 & 48 \\
\hline Total & 50 & 100 \\
\hline
\end{tabular}

TABLE XIII. SALARY CERTIFICATE

\begin{tabular}{|l|l|l|}
\hline Salary certificate & Number of hotels & Percentage \\
\hline Salary certificate & 50 & 100 \\
\hline Total & 50 & 100 \\
\hline
\end{tabular}

TABLE XIV. REQUeSt More CARBON SLIP

\begin{tabular}{|l|l|l|}
\hline Request more carbon slip & Number of hotels & Percentage \\
\hline Unable & 34 & 68 \\
\hline $\begin{array}{l}\text { Submit a form to the HR } \\
\text { department }\end{array}$ & 15 & 30 \\
\hline $\begin{array}{l}\text { Submit a form to the HR } \\
\text { department and forward email to } \\
\text { the accounting department }\end{array}$ & 1 & 2 \\
\hline Total & 50 & 100 \\
\hline
\end{tabular}

TABLE XV. PAYROLL SOFTWARE

\begin{tabular}{|l|l|l|}
\hline Payroll software & Number of hotels & Percentage \\
\hline exel & 2 & 4 \\
\hline Ace payroll & 13 & 26 \\
\hline Eagle & 14 & 28 \\
\hline AudiSoft & 1 & 2 \\
\hline TigerSoft & 2 & 4 \\
\hline Business Plus & 1 & 2 \\
\hline unknown & 12 & 34 \\
\hline Total & 50 & 100 \\
\hline
\end{tabular}

5) Learning and Training System

TABLE XVI. NOTIFICATIONS LEARNING AND TRAINING

\begin{tabular}{|l|l|l|}
\hline $\begin{array}{l}\text { Notification learning and } \\
\text { training }\end{array}$ & Number of hotels & Percentage \\
\hline By emailg & 13 & 26 \\
\hline By emailg and notice board & 23 & 46 \\
\hline $\begin{array}{l}\text { By emailg, notice board and } \\
\text { phone }\end{array}$ & 1 & 2 \\
\hline $\begin{array}{l}\text { By emailg, notice board and send } \\
\text { document as evidence }\end{array}$ & 2 & 4 \\
\hline
\end{tabular}

\begin{tabular}{|l|l|l|}
\hline $\begin{array}{l}\text { By emailg, notice board and } \\
\text { inform the department head when } \\
\text { meeting }\end{array}$ & 3 & 6 \\
\hline $\begin{array}{l}\text { By emailg, notice board and share } \\
\text { drive }\end{array}$ & 2 & 4 \\
\hline $\begin{array}{l}\text { By emailg, notice board and } \\
\text { sound public }\end{array}$ & 1 & 2 \\
\hline $\begin{array}{l}\text { send document to department } \\
\text { head }\end{array}$ & 1 & 2 \\
\hline $\begin{array}{l}\text { send document to department } \\
\text { head and notice board }\end{array}$ & 1 & 2 \\
\hline Call each department & 1 & 2 \\
\hline Notice board & 1 & 2 \\
\hline unknown & 1 & 2 \\
\hline Total & 50 & 100 \\
\hline
\end{tabular}

6) Knowledge Sharing within the Organization

TABLE XVII. KNOWLEDGE SHARING WITHIN THE ORGANIZATION

\begin{tabular}{|l|l|}
\hline Knowledge sharing & Number of hotels \\
\hline Morning meeting & 22 \\
\hline By social network & 16 \\
\hline Annual meeting & 8 \\
\hline Notification HR department & 9 \\
\hline Knowledge creation of employees & 1 \\
\hline Online surveys & 2 \\
\hline
\end{tabular}

\section{7) Evaluation System}

TABLE XVIII.EVALUATION SYSTEM

\begin{tabular}{|l|l|l|}
\hline Evaluation & Number of hotels & Percentage \\
\hline $\begin{array}{l}\text { Department head evaluated } \\
\text { through the paper only }\end{array}$ & 21 & 42 \\
\hline $\begin{array}{l}\text { Employees and department head } \\
\text { evaluated together through paper }\end{array}$ & 26 & 52 \\
\hline $\begin{array}{l}\text { Employees evaluated through } \\
\text { paper and department head } \\
\text { evaluated online }\end{array}$ & 3 & 6 \\
\hline Total & 50 & 100 \\
\hline
\end{tabular}

8) Benefits System

TABLE XIX. BENEFITS

\begin{tabular}{|l|l|}
\hline Benefits & Number of hotels \\
\hline Social security & 50 \\
\hline Other & 40 \\
\hline
\end{tabular}

9) Career Management System

TABLE XX. CAREER PROGRESSION

\begin{tabular}{|l|l|l|}
\hline Career & Number of hotels & Percentage \\
\hline $\begin{array}{l}\text { Organization consider the } \\
\text { education background, skills and } \\
\text { the evaluation from the top } \\
\text { executive to be the information to } \\
\text { plan for the position }\end{array}$ & 50 & 100 \\
\hline Total & 50 & 100 \\
\hline
\end{tabular}




\section{CONCLUSION}

The results assessed and summarized according to the eHRM's 9 important systems discussed above.

In conclusion, about 85 percent of the recruitment system had never applied the use of the e-HRM while another 15 percent had successfully implemented this newly developed technology. About 55 percent of the employment system uses the e-HRM and 45 percent had never applied the use of the eHRM. For the basic organizational information management system, 90 percent failed to apply the e-HRM and 10 percent agreed to use the e-HRM. Unfortunately, 100 percent of the salary management system had never developed the use of the e-HRM, similar to the learning and training system. The idea and creativity exchange system achieved only 38 percent while 62 percent had not prepared to use the e-HRM. About 94 percent of the assessment system has not managed to rely on the e-HRM, but another 6 percent appreciated the technology. Finally, the welfare system and the career development system were mutually down with 100 percent of the e-HRM illiteracy.

\section{RECOMMENDATION}

The hotel business operators with more than 200 guest rooms are considered as large organizations with tremendous investments generated to support the fast-growing tourism business immensely frequented by both local and foreign tourists. As a result, it is very important to apply the use of electronic technologies in the business aiming to greatly develop the skills and abilities of the employees while facilitating complicated work processes [35], [36]. Above all, today's common human resources management has been expected to be developed to the complete e-HRM with faster and better business efficiency.

\section{ACKNOWLEDGMENT}

This work was supported by the Research Fund of the Faculty of Technology and Environment, Prince of Songkla University (PSU), Phuket Campus, Thailand

\section{REFERENCES}

[1] Huub Ruël, Tanya Bondarouk and Jan Kees Looise, "E-HRM: Innovation or irritation. An explorative empirical study in five large companies on web-based HRM," Management Revue, Vol. 15, No. 3, Special Issue: Organizational Innovation and HRM, 2004, pp. 364-380.

[2] Stefan Strohmeier, "Research in e-HRM: Review and implications," Human Resource Management Review 17, 2007, pp. 19-37.

[3] Dianna L. Stone, Eugene F. Stone-Romero and Kimberly Lukaszewski, "Factors affecting the acceptance and effectiveness of electronic human resource systems," Human Resource Management Review 16, 2006, pp. 229-244.

[4] Sharyn D. Gardner, David P. Lepak and Kathryn M. Bartol, "Virtual HR: The impact of information technology on the human resource professional," Journal of Vocational Behavior 63, 2003, pp. 159-179.

[5] Kitimaporn Choochote, "Factors affecting the selection of Boutique Hotel of tourist in Phuket Province," International Journal of Business and Management Study, September 2014; Vol. 1(3), ppt. 137-140.

[6] Parry, Emma, "An examination of e-HRM as a means to increase the value of the HR function," The International Journal of Human Resource Management, May 2011, pp. 1146-1162.

[7] Laumer, Sven, Andreas Eckhardt, and Tim Weitzel, "Electronic human resources management in an e-business environment," Journal of Electronic Commerce Research, 2010, pp. 240.
[8] Swaroop, Mr K. Reddi, "E-HRM and How It Will Reduce the Cost in Organization," Asia Pacific Journal of Marketing \& Management Review, Vol.1 (4), December (2012), pp. 133-139.

[9] Mary, C. M., and Nayagi Kunthala, "A Study On The Present And Emerging Trends In E-HRM and HRIS In The Hindu," International Journal of Management, IT and Engineering 2.7, 2012, pp. 178-187.

[10] Kitsiri Chochiang and Kitimaporn Choochote, "9 Procedures for the Effective E-RM,"International Conference on Strategic Business Management (ICSBM 2013), Kuala Lumpur, Malaysia, 4 - 6 July 2013, pp. 28-37.

[11] Sven Laumer and Andreas Eckhardt, "Help to Find the Needle in a Haystack - Integrating Recommender Systems in an IT supported Staff," 47th annual conference on Computer personnel research, 2009, pp. 7-12.

[12] Khosla, Rajiv, "An online multi-agent e-sales recruitment system," Web Intelligence, 2003. WI 2003. Proceedings. IEEE/ WIC International Conference on IEEE, 2003.

[13] Sylva, Hella, and Stefan T. Mol, "E-Recruitment: A study into applicant perceptions of an online application system," International Journal of Selection and Assessment 17.3, 2009, pp. 311-323.

[14] Nickel, Jennifer, and Heike Schaumburg, "Electronic privacy, trust and self-disclosure in e-recruitment," CHI'04 Extended Abstracts on Human Factors in Computing Systems, ACM, 2004.

[15] Greiner, Ben , “ An Online Recruitment System for Economic Experiments," Published in Forschung und wissenschaftliches Rechnen 2003, GWDG Bericht, Vol. 63, 2004, pp. 79-93.

[16] Tong, David Yoon Kin, "A study of e-recruitment technology adoption in Malaysia," Industrial Management \& Data Systems 109.2, 2009, pp. 281-300.

[17] Stone, Dianna L., and James H. Dulebohn, "Emerging issues in theory and research on electronic human resource management (eHRM)," Human Resource Management Review 23.1, 2013, pp. 1-5.

[18] Parry, Emma, and Shaun Tyson, "Desired goals and actual outcomes of e-HRM," Human Resource Management Journal 21.3, 2011, pp. 335354.

[19] Mehrjoo, Davood, and Mehdi Noursina, "The Relationships between eHRM and Staff Empowerment: A Case Study of Amir Al-Moemenin Hospital in Iran," 2013.

[20] Gupta, Anjali, and Shahnam Saxena, "Electronic Human Resource Management (e-HRM): Growing Role in Organizations," Management Insight 8.1, 2013.

[21] Pinki J Nenwani and Manisha D Raj, " E-HRM Prospective in Present Scenario ," International Journal of Advance Research in Computer Science and Management Studies, Volume 1, Issue 7, December 2013, pp. 422-428.

[22] Alshibly, Haitham Hmoud, "Evaluating E-HRM success: A Validation of the Information Systems Success Model," International Journal of Human Resource Studies 4.3, 2014, pp. 107.

[23] Davenport, Thomas H, "Putting the enterprise into the enterprise system," Harvard business review 76.4, 1998.

[24] Osama Harfoushi, Ruba Obiedat, "E-Training Acceptance Factors in Business Organizations," International Journal of Emerging Technologies in Learning, Vol 6, No 2, 2011, pp. 15-18.

[25] Bagnasco, Andrea, et al, "A model for an open and flexible e-training platform to encourage companies' learning culture and meet employees' learning needs," Educational Technology \& Society 6.1, 2003, pp. 5563.

[26] Barron, Tom, "A smarter Frankenstein: The merging of e-learning and knowledge management," Learning Circuits 1.8, 2000.

[27] Woelk, Darrell, and Shailesh Agarwal, "Integration of e-learning and knowledge management," World Conference on E-Learning in Corporate, Government, Healthcare, and Higher Education, Vol. 2002 No. 1, 2002.

[28] Jarvenpaa, Sirkka L., and D. Sandy Staples, "The use of collaborative electronic media for information sharing: an exploratory study of determinants," The Journal of Strategic Information Systems 9.2, 2000, pp. 129-154. 
[29] Raban, Daphne R., and Sheizaf Rafaeli, "Investigating ownership and the willingness to share information online," Computers in Human Behavior 23.5, 2007, pp. 2367-2382.

[30] Robles, Marcel, and Sandy Braathen, "Online assessment techniques," Delta Pi Epsilon Journal 44.1, 2002, pp. 39-49.

[31] Kahn, David, et al, "System for web-based payroll and benefits administration," U.S. Patent No. 20,020,184,148, 5 Dec, 2002.

[32] Greengard, Samuel, "Putting HR software to work," Workforce 9, 1999, pp. 4-10.
[33] Leibowitz, Zandy B., and Nancy K. Schlossberg, "Training Managers for Their Role in a Career Development System," Training and Development Journal 35.7, 1981, pp. 72-79.

[34] Walz, Garry R, "Career Development in Organizations," 1982.

[35] Olivas-Lujan, Miguel R., Jacobo Ramirez, and Laura Zapata-Cantu, "eHRM in Mexico: adapting innovations for global competitiveness." International Journal of Manpower 28.5, 2007, pp. 418-434.

[36] Ruel, Huub JM, Tanya V. Bondarouk, and Mandy Van der Velde, "The contribution of e-HRM to HRM effectiveness: Results from a quantitative study in a Dutch Ministry," Employee Relations 29.3, 2007, pp. 280-291 